2) R. Pribil, V. Vesely : ibid., 11, 1319 (1964).

3) R. Pribil, V. Vesely : ibid., 11, 1545 (1964).

4) 上野景平：“キレート滴定法”， p. 198 (1956), (南江堂).

5) T. A. Bohigian, Jr., A. E. Martell : Inorg . Chem., 4, 1264 (1965).

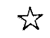

Chelometric titration with TTHA. Atsuko Iто and Keihei Ueno (Faculty of Engineering, Kyushu University, Hakozaki, Fukuoka-shi)

Chelometric titration of various metal ions with TTHA (Triethylenetetraminehexaacetic acid) can be performed in quite similar way as that with EDTA. The color changes of indicators are, however, sluggish in general, and some of them give end points hardly distinguishable.

in As suggested by Pribil, the mixture of metal ions which react with TTHA in the ratio of $1: 1$ and $2: 1$ (metal : ligand), respectively, may be titrated selectively. In the mixture of calcium and magnesium taken as the first case, however, it was unsuccessful to find an optimum condition which was common for both ions. Among the other combinations of metal ions such as the mixtures of calcium with nickel, zinc and cadmium, the mixtures of cerium with lead, zinc and mercury, and the mixtures of lanthanum with lead, zinc and cobalt, a satisfiable result was obtained only in the mixture of lanthanum and mercury.

In order to evaluate the TTHA titration, the theoretical titration curves of calcium and magnesium were derived by calculations using the equilibrium data of $1: 1,2: 1$ and $3: 1$ complexes, as well as monohydrogen and di-hydrogen complexes. Somewhat sluggish color change of the indicator near the end point is explained by the increase of $\mathrm{pM}$ at the earlier stage of titration.

(Received Sept. 25, 1967)

\title{
溶解度差を利用するヨウ素イオンとヨウ素酸イオン 混合物の電流滴定
}

\author{
武者 宗一郎*，池田 早苗，西田 義郎**
}

\begin{abstract}
ヨウ素イオンとヨウ素酸イオンを両者共存のまま，示差的に定量する電流滴定法を提案する. ヨウ素 イオンとヨウ素酸イオンはともに銀イオンと反応し銀塩として沈殿するが，常温の水に対する溶解度に 格段の差があることと，ヨウ化銀はうすいアンモニア性溶液に難溶性であるが，ヨウ素酸銀は易溶性で あることに基づき，回転白金電極を指示電極，S. C. E. またはヨウ化水銀（II）電極を対極とする短絡 電流滴定法によって，両イオンを定量する 2 種類の方法について検討を加えた.

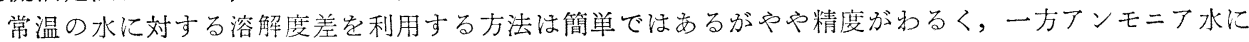
対する溶解度差に基べく方法は 2 回の滴定を必要とするが，精度においてすぐれているという特長を持 っている。
\end{abstract}

\section{1 緒言}

ヨウ素酸塩の代表的製法1)の一つとして，ヨウ化物の 水溶液を電解酸化する方法がある. また一般にヨウ化物 とヨウ素酸塩は共存することが多いので，両者の混合物 を共存状態のまま定量する方法を確立することは, 工業 的にも意義が大きいと考えられる.

ヨウ素イオンまたはヨウ素酸イオンの個々の定量法2)

* 大阪府立大学工学部応用化学科 : 大阪府堺市百舌鳥 梅町 4 丁目

** 德島大学工業短期大学部応用化学科 : 德島市南常三 島町 2 丁目
は数多くあるが，共存する両者它迅速簡易に定量する方 法沙ない，岩崎らは比色法によるこれらの定量法了立 報告しているが，回転白金電極它用いた電流滴定法によ って，これらの混合物を示痓的に銀滴定する方法法報告 されていない。

著者らはさきに溶解度差を利用する電流滴定法によっ てチオシアン酸イオンとシアン酸イオンの混合系などの 定量方法4) を検討し，その結果老報告した。今回はヨウ 素イオンとヨウ素酸イオンが銀イオンと反応して生成与 るヨウ化銀とヨウ素酸銀の篮温の水また法アンモニア水 に対する溶解度に格段の差があることに着目し, 両者を 電流滴定する方法を検討した. 
ヨウ素イオンの電流滴定については Laitinen $5^{5), ~}$ Kolthoff ら6)の報告にあるように，アンモニアアルカリ 性，中性抢よび酸性の妄い $\mathrm{pH}$ 領域にわたって銀滴定が 可能である.しかるにヨウ秦酸イオンは銀イオンと反応 して生成するヨウ集酸銀の水に刘吉る溶解度が大きいて たわ，常温の水溶液としては亚確な滴定ができないの で，まずヨウ媇酸イオンの滴定条件について検討を加 え, 引き続きヨウ䕀イオンとヨウ素酸イオンの混合系に 対古万筀星方法老検討した。

\section{2 装置，試藥および実験方法}

\section{$2 \cdot 1$ 装}

既報4とほぼ同様のものを用いた．白金電極の前処理 なども同棑なお法によった。な被滴定液の温度調節に は小松需子の雷子恒温衙環装置 “Coolnics” CTE-1A 型を用いた． $5^{\circ} \mathrm{C}$ 以下に泠却して滴定する場合は，滴定 セルを氷水中に浸しながら行なら4ことも可能であった。

\section{2 試 薬}

$0.1 F$ ヨウ化カリウム溶泣: 和光純薬の試薬特級ヨウ 化カリウム定再蒸留水に浴解し, Volhard 法で標定した

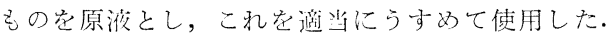

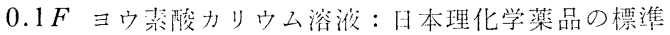
試薬ヨウ装酸カリウム落 $110^{\circ} \mathrm{C}$ で恒量になるまで乾燥

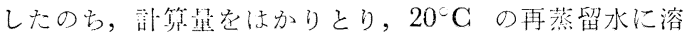
解して調製した。

$1 F$ アンモニア水：和光純薬の試薬特級アンモニア水 をうすめて用いた。

この他の試薬はすべて特級品を用いた。

\section{$2 \cdot 3$ 実験方法}

$200 \mathrm{ml}$ のふ・们の瀜定セルに一定量のヨウ化カリウ ム溶液とヨウ楽舼カリウム溶液をはかりとり，支持電解

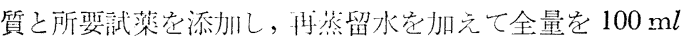

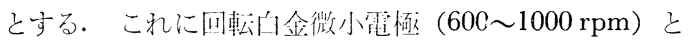

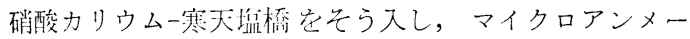
ター岁汇さえで飽和力ロメル電極またはヨウ化水銀 (II)

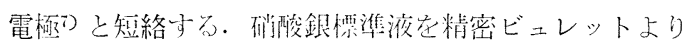
適当量㵜加与をごとにマグネティックスターラーでじゅ うぶえかき混ぜたのも归め，指針の静止炎待って指示電

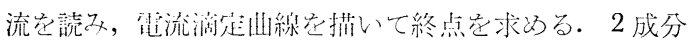

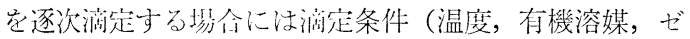
ラチン， $\mathrm{pH}$ 衣ど）虹変况てき続き同様に滴定して第 二の終点堂求以る.

\section{3 实験結果㧍よび考察}

\section{1 ヨウ素酸イオンの電流滴定}

3.1.1 温度の影響 $\quad 0.1 F$ ヨウ素酸 カリウム溶液
$10 \mathrm{ml}$ を正確にはかりとり，支持電解質として $1 F$ 硝 酸カリウム $10 \mathrm{ml}$ を加え, $0.5 \%$ ゼラチン溶液 $4 \mathrm{ml}$ と 再蒸留水を添加して全量を $100 \mathrm{~m} l$ とする. この試料溶 液の温度を適当に調節したのち，回転白金電極と S. C. E. を用いて $0.1 F$ 硝酸銀標準液で電流滴定した結果を Fig. 1 亿示す.

いずれの場合にも滴定の初期 $(0.1 F$ 硝酸銀約 $1 \mathrm{ml}$ 添加するまでの間）にかなり大きな指示電流が認められ るが，これを過ぎるとほぼ一定の值を示すので，スター ラーでじゅうぶんかき混ぜて指針が落ち着いてから電流 值を読みとり電流滴定曲線を作成した。

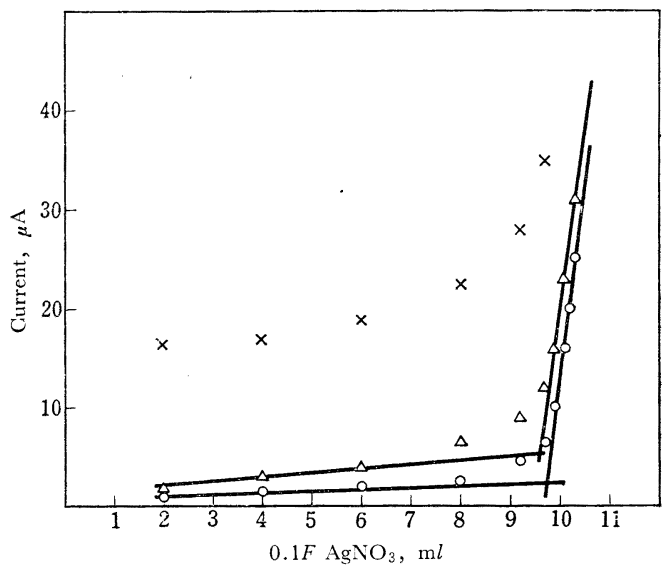

Fig. 1 Effect of temperature on the amperometric titration curves of iodate ion $100 \mathrm{~m} l$ of $0.01 F \mathrm{KIO}_{3}, 0.1 F \mathrm{KNO}_{3}, 0.02 \%$ gelatin, $\times 31^{\circ} \mathrm{C}, \triangle 11^{\circ} \mathrm{C}, \bigcirc 5^{\circ} \mathrm{C}$

Fig. 1 のように被滴定液の温度が $31^{\circ} \mathrm{C}$ の場合に泣， 明確な滴定曲線が得られず，正確な滴定法不可能であっ た。これはヨウ素酸銀の溶解度が高いため生じた銀イオ ンの還元電流によるものと考えら机るので, 滴定時の温 度を下げて滴定孛試みた. $11^{\circ} \mathrm{C}$ の場合には $4 \%$ 前後の 負の詥差を伴らが明確な終点を示すことがわかった。さ らに温度を下げて $5^{\circ} \mathrm{C} て ゙$ て滴定すると明確な滴定曲線が 得られ, 誤差も約 $1 \%$ の負の終点が得られることが明ら かになった・ただし，滴定温度を低くするとヨウ素酸イ オンと銀イオンの反応速度が小さく, 滴定の初期に極大 現集が生じ，滴定時間が相当長くかかる傾向が認心られ た・この点については別に報告する予定である。したが ってヨウ素酸イオン艺筈温で直接銀湳定することは困難 であるが， $5{ }^{\circ} \mathrm{C}$ 以下に泠却して滴定するとやや負の誤差 を伴らが定量可能なことが明らかになった。

3.1.2 ゼラチン添加の効果 2 個の滴定セルに0.1 
$F$ ヨウ素酸カリウム溶液 $10 \mathrm{~m} l$ と支持塩として $1 F$ 硝 酸カリウム溶液 $10 \mathrm{~m} l$ 定はかり取り，一才汇注再蒸留水 加えて $100 \mathrm{ml}$ とし，他方には $0.5 \%$ ゼラチン溶液 $4 \mathrm{~m} l$ と再蒸留水を加えて $100 \mathrm{ml}$ 上卞る. 両者を約 $3^{\circ} \mathrm{C}$ に泠却しながら $0.1 F$ 硝酸銀慓準液でそれぞれ電流淌定 すると, Fig. 2 のような滴定曲線が得られた。

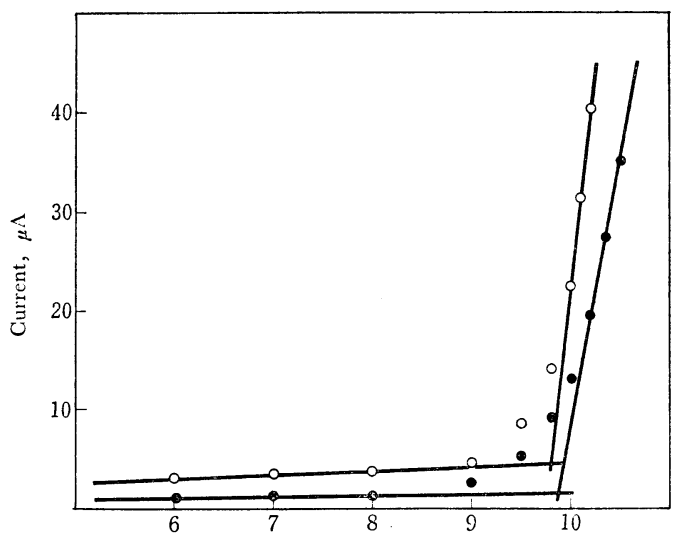

$0.1 F \mathrm{AgNO}_{3}, \mathrm{~m} l$

Fig. 2 Effect of gelatin on the amperometric titration curves of iodate ion

$100 \mathrm{~m} l$ of $0.01 F \mathrm{KIO}_{3}, 0.1 F \mathrm{KNO}_{3}$, at $3^{\circ} \mathrm{C}$, Without gelatin ( 1 ), With $0.02 \%$ gelatin (2)

ゼラチン堂添加しない場合には曲線（1）のよう滴 定の初期からかなり大きな残余電流が認められ，終点も 計算值と比べてやや大き襀の䛊差を寺元た。一方， 0.02\%のゼラチンを添加した場合には曲線（2）のよう 飞和り, 残余電流も比較的小さく, 終点为計算值记近い 結果が得ら机ることが明らか心なった。こ机はゼラチン の保讙コロイド作用仁上ってヨウ絜酸銀に基ゔく還元電

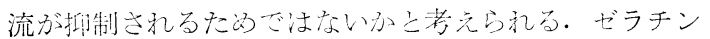

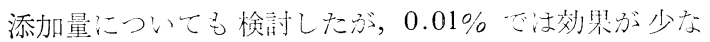
く，また $0.05 \%$ 以上の場合化电特江良好子絬果法得ら れず，けっきょく，0.02〜0.03\% が最適であることを 実験的に確認した。

3.1.3 有機溶媒添加の効果 $0.1 F$ ヨウ素酸力リウ ム溶液 $10 \mathrm{~m} l, 1 F$ 硝酸カリウム溶液 $10 \mathrm{ml}$ 出よで $0.5 \%$ ゼラチン溶液 $4 \mathrm{ml}$ 在法かり取り, こ机化一定量の有機溶 媒学添加したのち再蒸留水索加えて全量を $100 \mathrm{ml}$ 亡す る. $0.1 F$ 硝酸銀標準液を用いて常温でこれを滴定し， 有機溶媒添加の効果検討した。 その絬果在 Fig. 3 に 示吉.

曲線（1）汇有機溶媒它添加しない場合の滴定曲線で，

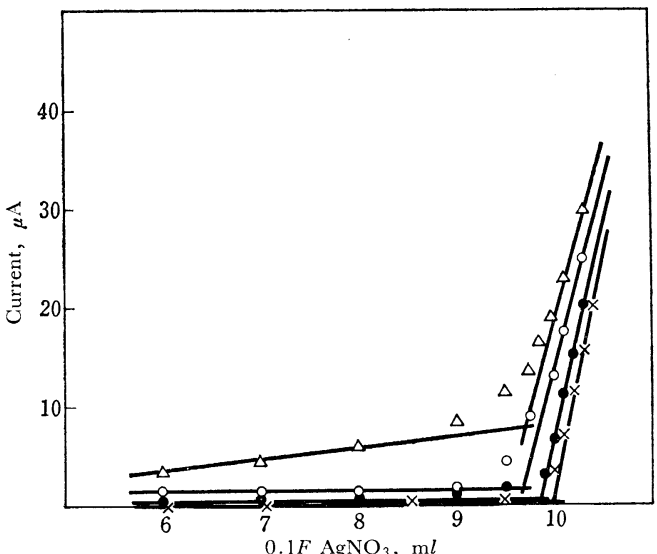

Fig. 3 Effect of organic solvent on the amperometric titration curves of iodate ion

$100 \mathrm{~m} l$ of $0.01 F \mathrm{KIO}_{3}, 0.1 F \mathrm{KNO}_{3}, 0.02 \%$ gelatin at $21^{\circ} \mathrm{C}, \triangle$ Without organic solvent (1), $\bigcirc 25 \mathrm{vol} \%$ methanol (2), 40 vol\% methanol (3), $\times 35$ vol\% ethanol (4)

比較のた放に示したものである・メタノール赏添加した

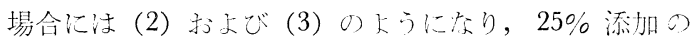

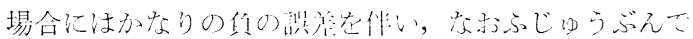

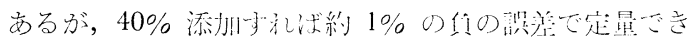
た.

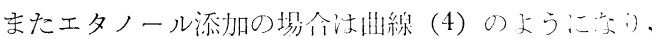

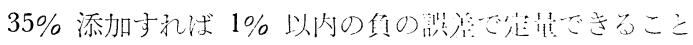

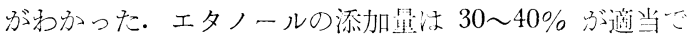
これ以上用いても好結果洦ら机なかった。

したがって，有機溶媒としてはメタノール，アセトン （Table I）も使用可能であるが，30〜40\% のエタノー

Table I Amperometric titrations of iodate ion under various conditions

\begin{tabular}{|c|c|c|c|c|c|c|c|}
\hline \multicolumn{3}{|c|}{ Concentration $(F)$} & \multirow{2}{*}{$\begin{array}{c}\text { Gelatin } \\
(\%)\end{array}$} & \multirow{2}{*}{\multicolumn{2}{|c|}{$\begin{array}{c}\text { Organic } \\
\text { solvent } \\
(\text { vol } \%)\end{array}$}} & \multirow{2}{*}{$\begin{array}{c}\text { Temp. } \\
\left({ }^{\circ} \mathrm{C}\right)\end{array}$} & \multirow{2}{*}{$\begin{array}{c}\text { Relative } \\
\text { error } \\
(\%)\end{array}$} \\
\hline $\mathrm{IO}_{3}^{-}$ & $\mathrm{Ag}^{+}$ & $\mathrm{KNO}_{3}$ & & & & & \\
\hline 0.01 & 0.1 & 0.1 & 0.02 & & - & 17 & -5.1 \\
\hline "I & "I & "I & $" \prime$ & & - & 10 & $-3 . t$ \\
\hline "I & " & "I & " & & - & 3 & -0.9 \\
\hline "I & " & " & - & & - & 3 & -2.8 \\
\hline$" \prime$ & " & $" \prime$ & 0.02 & $30 \%$ & $\mathrm{C}_{2} \mathrm{H}_{5} \mathrm{OH}$ & 18 & -0.8 \\
\hline "I & 11 & $" \prime$ & "I & $35 \%$ & $1 "$ & 12 & -0.7 \\
\hline "I & "I & " & " & $" 1$ & $" 1$ & 3 & -0.5 \\
\hline "I & "I & " & - & "I & " & "I & -2.1 \\
\hline " & "I & $" \prime$ & 0.02 & $40 \%$ & "I & 8 & -0.8 \\
\hline $1 "$ & $" 1$ & " & $" 1$ & $" 1$ & $\mathrm{C}_{\mathrm{H}} \mathrm{H}_{3} \mathrm{OH}$ & 13 & -0.9 \\
\hline "I & " & " & "l & " & $\left(\mathrm{C} \mathrm{H}_{3}\right)_{2} \mathrm{CO}$ & 16 & -1.8 \\
\hline 0.005 & 0.1 & 0.1 & " & & - & 3 & -1.4 \\
\hline 0.002 & " & " & "I & & - & " & -3.2 \\
\hline 0.001 & "I & "I & "I & & - & "I & Impossible \\
\hline
\end{tabular}

$\dagger$ Average of 4 determinations 
ルを添加与るのが最檤であることが明らかになった。な お有機溶媒定この程度添加しても父注うが発生して滴定 に悪影響空及ぼす上いう傾向注涊的ら机なかった。

3.1.4 ヨウ素酸イオンの定量結果 ヨウ素酸イオン

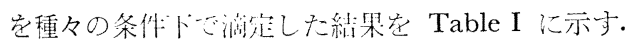

Table I 和以明らかなように, ヨウ索酸イオン常温

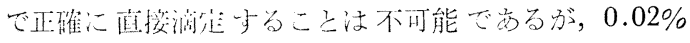

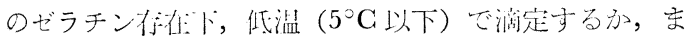
た常温では 30〜40\%のエタノール宗た泣メタノール定 添加して滴分上马ことによって粗度よく定量与るこ上が できた。

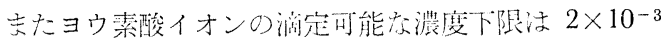
$F$ 程度までで，10-3F になる上明確な終点老示さなく なること架实駼的に明らかになった。

\section{2 ヨウ素イオンとヨウ素酸イオン 混合物の電流滴} 定

3.2.1 水に対する溶解度差を利用する方法 $ヨ ウ$ 化 銀之ヨウ素酸銀の管温の水に対する溶解度差に基づくも ので，ヨウ素イオンが比較的高温 $\left(20 \sim 35^{\circ} \mathrm{C}\right)$ でも精度 よく銀滴宝できるのに対し，ヨウ素酸イオン湔前述のよ

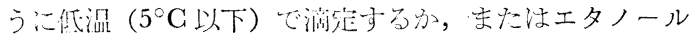
などの有機溶媒定添加して，溶解度を下げないと精度よ く滴定でき沵いという性犋在利用し，高温洔のヨウ素酸 銀の解潍による指示電流によってヨウ装イオンの終点觉

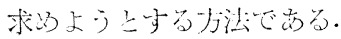

（1）分析操作上滴定曲線：分析操作の 1 例者示与上 次のようになる。，滴定セルに0.1F ヨウ化カリウム溶液 $10 \mathrm{~m} l, 0.1 F$ ヨウ菜酸 カリウム溶液 $10 \mathrm{~m} l$, 字よび支 持電解質乞して $1 F$ 硝酸カリウム溶液 $10 \mathrm{~m} l$ 走之り,

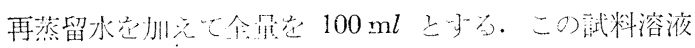

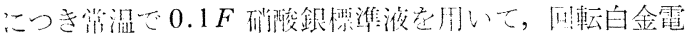

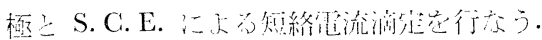

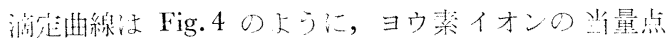

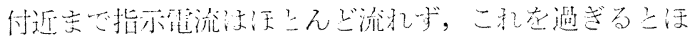

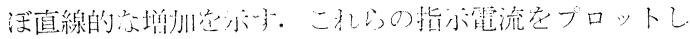

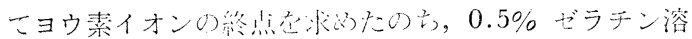

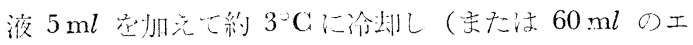
タノールを添版て $20^{\circ} \mathrm{C}$ 前後べ）滴定老䋨ける之ヨウ

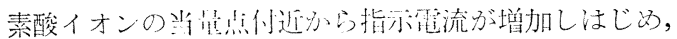
過剩の銀イオン汇上って遖線的な增加在示守のでヨウ素

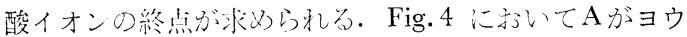
素イオンの終点荧示し，Bがヨウ素イオンとヨウ素酸イ オンの合計量の終点沉相当与るので，ヨウ素酸イオンは $\mathrm{B}-\mathrm{A}$ から求的ら机る。

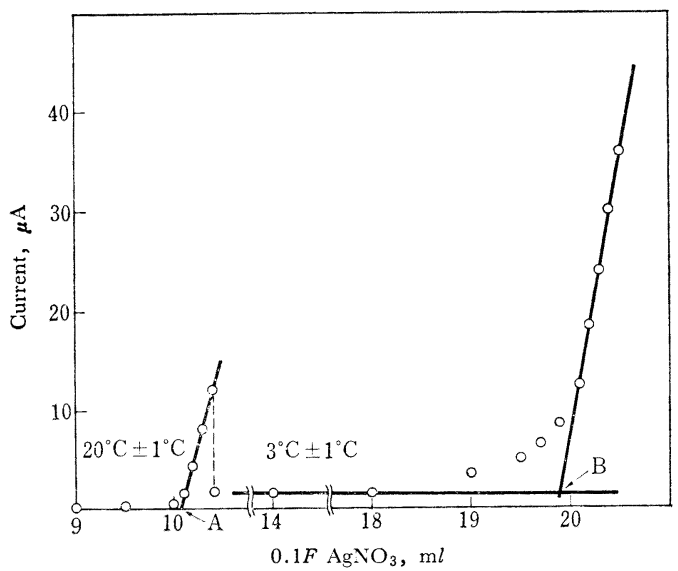

Fig. 4 Successive amperometric titration curve of the mixture of iodide and iodate ion $100 \mathrm{~m} l$ of $0.01 F \mathrm{KI}, 0.01 F \mathrm{KIO}_{3}, 0.1 F \mathrm{KNO}_{3}$, $0.02 \%$ gelatin, $\mathrm{I}^{-}=\mathrm{A}, \mathrm{IO}_{3}-\cdots \mathrm{B}-\mathrm{A}$

（2）支持電解質の吟味（ $\mathrm{pH}$ の影響）：支持電解質 として $0.1 F$ 硝酸力りウム溶液を用いて $\mathrm{pH}$ 6.6 6.8 でヨウ素イオンとヨウ素酸イオンの混合溶液を逐次電流 滴定すると，一般にヨウ素イオンには正の誤差を生じ， ヨウ素酸イオンには負の誤在尘ずる傾向が認的られ

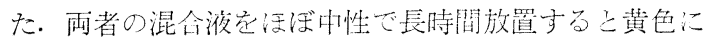
着色してくることと，婹老和引゙かて源加してもかっ色に なるこ上和ら，(1) 式のように反応してヨウ素遊離 し，こ机がヨウ素イオンとともに銀イオンと反応してヨ ウ化銀を生成主るた放，ヨウ䇣イオンの滴定值が大きく なり，その分だけヨウ素酸イオンの定量值が小さくなる もの之教无的机る。

$$
5 \mathrm{I}^{-}+\mathrm{IO}_{3}^{-}+6 \mathrm{H}^{+}=3 \mathrm{I}_{2}+3 \mathrm{H}_{2} \mathrm{O}
$$

以上のような現像が認的られたのた，硝酸カリウムの ほかに硝酸アンモニウム, 酶酸アンモニウムおうび酶酸 ナトリウム在支持電解質上乙て滴定し，被滴定液の $\mathrm{pH}$

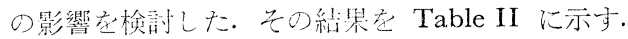

Table II 的ら明らかなよう汇， $0.1 F$ 硝酸アンモニウ 厶它支持電解質と年る場合飞注，ヨウ素イオンの正の誤 差分最も大きくなるとともにヨウ素酸イオンの負の誤差 も大きくなる傾向が羿奶られた．酶酸?ンモ二ウムまた 注䤃酸ナトリウムを用いた場合に法，一般に両者の誤差 がそ机ぞ机小さくなる傾向注あるが，硝酸カリウムを支

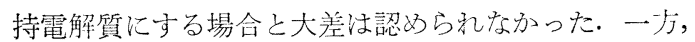
$\mathrm{pH} 8$ 以上のアルカリ側で法銀イオンの拡散電流が得ら れにくくなるので，支持電解質として法硝酸カリウム， 
Table II Successive titrations of iodide and iodate ion

\begin{tabular}{|c|c|c|c|c|c|c|c|c|}
\hline \multicolumn{3}{|c|}{ Concentration $(F)$} & \multirow{2}{*}{\multicolumn{2}{|c|}{ Media }} & \multirow{2}{*}{$\mathrm{pH}$} & \multicolumn{2}{|c|}{ Relative error $(\%) \dagger$} & \multirow{2}{*}{ Remarks } \\
\hline $\mathrm{I}^{-}$ & $\mathrm{IO}_{3}^{-}$ & $\mathrm{Ag}^{+}$ & & & & $\mathrm{I}^{-}$ & $\mathrm{IO}_{3}^{-}$ & \\
\hline 0.01 & 0.01 & 0.1 & $0.1 F$ & $\mathrm{NH}_{4} \mathrm{NO}_{3}$ & 5.6 & +2.2 & -3.0 & Cooling for $\mathrm{IO}_{3}^{-}$ \\
\hline "I & "I & "I & "I & $\mathrm{KNO}_{3}$ & 6.6 & +1.2 & -1.8 & " \\
\hline " & " & " & " & $\mathrm{CH}_{3} \mathrm{COONH}_{4}$ & 7.0 & +0.9 & -1.0 & $\prime \prime$ \\
\hline " & "I & "I & "I & $\mathrm{CH}_{3} \mathrm{COONa}$ & 7.8 & +0.5 & -1.3 & " \\
\hline 0.001 & 0.01 & 0.1 & $0.1 F$ & $\mathrm{KNO}_{3}$ & 6.7 & -0.6 & -1.3 & " \\
\hline 0.002 & 0.01 & 0.1 & $0.1 F$ & $\mathrm{KNO}_{3}+35 \% \quad \mathrm{C}_{2} \mathrm{H}_{5} \mathrm{OH}$ & - & +0.2 & -0.8 & Adding $\mathrm{C}_{2} \mathrm{H}_{5} \mathrm{OH}$ for $\mathrm{IO}_{3}-$ \\
\hline
\end{tabular}

$\dagger$ Average of 4 determinations

䣷酸アンモニウム，および酢酸 ナトリウムなどが適当 で, $\mathrm{pH}$ は 6.6〜7.8 程度で滴定すべきであると考えら 机る。

\section{$3 \cdot 2 \cdot 2$ アンモニア水に対する 溶解度差を 利用する方} 法

ヨウ化銀がアンモニア水に難溶性であるのに対して， ヨウ素酸銀が易溶性であるため，こ机らの混合物をアン モニア性で電流滴定すると，ヨウ素酸イオン（または䘏 素イオン，系素イオンなど）の妨宫花受けることなくヨ ウ素イオンを定量することができる. 続いて被滴定液を 中性に乙て滴定すれば，ヨウ素酸イオンをも定量できる ものと考えられる. しかしここでは精度よく両者を定量 する目的た，同一試料溶液を別に分取し硝酸カリウム， ゼラチンおよびェタノールを添加してほぼ中性溶液を調 製し，泠却したの方滴定してヨウ素イオンとヨウ素酸イ オンの合計量を求める方法を用い，2 回の滴定によって 両者定定量する方法を検討した.

（1）アンモニア性溶液におけるヨウ素酸イオンと共 存するヨウ素イオンの電流滴定：分析操作の1例を示す と次のようになる。 $0.1 F$ ヨウ化力リウム溶液と $0.1 F$ ヨウ素酸カリウム溶液をそれぞれ $10 \mathrm{ml}$ はかりとって滴 定セルに入れ， $1 F$ 硝酸力リウム溶液と $1 F$ アンモニア 水条 $10 \mathrm{ml}$ と $0.5 \%$ ゼラチン溶液 $4 \mathrm{ml}$ を添加し, 再 蒸留水を加えて全量を $100 \mathrm{ml}$ とする。乙れに回転白金 電極とヨウ化水銀 (II) 電極を用いる短絡電流滴定法8) を適用し， $0.1 F$ 硝酸銀標準液で滴定する。

滴定曲線注 Fig. 5 の（1）のようになり，当量点付近 まで指示電流はほとえど流礼ないが，これを過ぎると銀 アンモニウム錯イオンの捻散電流によって直線的な增加 を示すので，ヨウ装イオンの終点 (A) 学求的ることが できる。

定量結果は Table III のようになる。

Table III から明らかなように，ヨウ素酸イオンが 10 倍以上共存しても $0.1 F$ アンモニアアルカリ性で電流滴 定寻ればほほとえどとの影留を受けることなくヨウ素イ

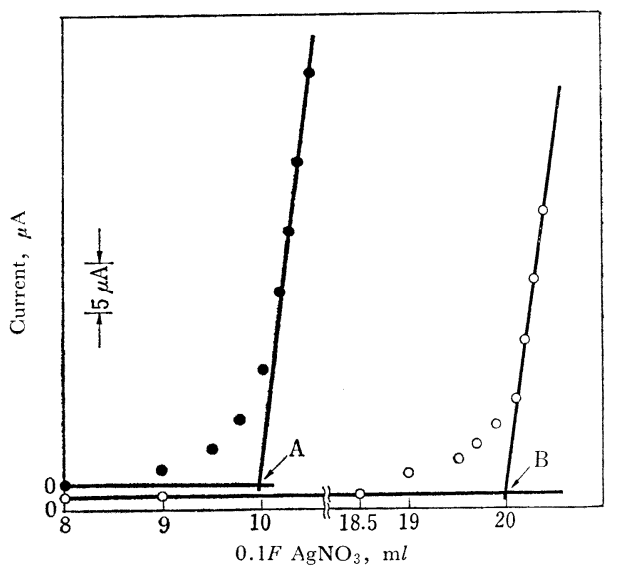

Fig. 5 Amperometric titration curves of the mixture of iodide and iodate ion

- $100 \mathrm{ml}$ of $0.01 F \mathrm{KI}, 0.01 F \mathrm{KIO}_{3}, 0.1 F \mathrm{KNO}_{3}$, $0.1 F \mathrm{NH}_{4} \mathrm{OH}, 0.02 \%$ gelatin at $20^{\circ} \mathrm{C}$, Reference : $\mathrm{HgI}_{2}$ electrode (1); $\bigcirc 100 \mathrm{ml}$ of $0.01 F \mathrm{KI}, 0.01 F \mathrm{KIO}_{3}$, $0.1 F \mathrm{KNO}_{3}, 0.02 \%$ gelatin, $35 \mathrm{vol} \%$ ethanol at $4^{\circ} \mathrm{C}$, Reference : S. C. E. (2), $\mathrm{I}^{-}=\mathrm{A}, \mathrm{IO}_{3}^{-}=\mathrm{B}-\mathrm{A}$

Table III Determination of iodide ion in ammoniacal solutions in the presence of iodate

\begin{tabular}{|c|c|c|c|c|c|c|}
\hline \multicolumn{5}{|c|}{ Concentration $(F)$} & \multirow{2}{*}{$\begin{array}{l}\text { Temp. } \\
\left({ }^{\circ} \mathrm{C}\right)\end{array}$} & \multirow{2}{*}{$\begin{array}{c}\text { Relative } \\
\text { error }{ }^{\dagger} \\
(\%)\end{array}$} \\
\hline $\mathrm{I}^{-}$ & $\mathrm{IO}_{3}^{-}$ & $\mathrm{Ag}^{+}$ & $\mathrm{KNO}_{3}$ & $\mathrm{NH}_{3} \mathrm{aq}$. & & \\
\hline 0.01 & - & 0.1 & 0.1 & 0.1 & 15 & -0.4 \\
\hline "I & 0.01 & "I & "I & " & 16 & -0.3 \\
\hline " & 0.005 & " & "I & " & "' & $\div 0.2$ \\
\hline 0.005 & 0.01 & "I & "I & " & "l & -0.5 \\
\hline 0.001 & "I & "I & "I & "I & 13 & -0.7 \\
\hline "I & "I & 0.01 & 0.01 & "I & " & $-0 . \overline{5}$ \\
\hline " & 0.001 & "I & "I & "I & "I & -0.2 \\
\hline 0.0001 & 0.01 & 0.001 & "I & " & "I & $\div 6.8$ \\
\hline
\end{tabular}

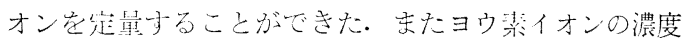

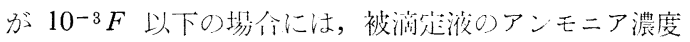
は $10^{-3} \mathrm{~F}$ 以下にしたほうが粘庭のよい綪鼠在与光た。

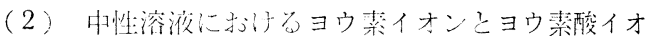


Table IV Determination of the total amount of iodide and iodate ion

\begin{tabular}{|c|c|c|c|c|c|c|c|c|c|}
\hline \multicolumn{4}{|c|}{ Concentration $(F)$} & \multirow{2}{*}{\multicolumn{2}{|c|}{$\begin{array}{l}\text { Organic } \\
\text { solvent } \\
\text { (vol\%) }\end{array}$}} & \multirow{2}{*}{$\begin{array}{c}\text { Temp. } \\
\left({ }^{\circ} \mathrm{C}\right)\end{array}$} & \multicolumn{3}{|c|}{ Relative error $(\%)^{\dagger}$} \\
\hline $\mathrm{I}^{-}$ & $\mathrm{IO}_{3}^{-}$ & $\mathrm{Ag}^{+}$ & $\mathrm{KNO}_{3}$ & & & & $\mathrm{I}^{-}+\mathrm{IO}_{3}^{-}$ & $\mathrm{I}^{-}$ & $\mathrm{IO}_{3}-$ \\
\hline 0.01 & 0.01 & 0.1 & 0.1 & & - & 3 & -0.8 & -0.3 & -1.3 \\
\hline " & " & $" \prime$ & $" \prime$ & $20 \%$ & $\mathrm{C}_{2} \mathrm{H}_{5} \mathrm{OH}$ & 3 & -0.6 & -0.3 & -0.9 \\
\hline "I & " & " & $" \prime$ & $30 \%$ & " & 3 & -0.3 & -0.3 & -0.3 \\
\hline "I & " & $" \prime$ & " & $40 \%$ & " & 4 & +0.1 & -0.3 & +0.5 \\
\hline " & 0.005 & " & " & " & " & 5 & -0.4 & +0.2 & -1.6 \\
\hline 0.001 & 0.01 & " & "I & $35 \%$ & " & 3 & -0.7 & -0.7 & -0.6 \\
\hline 0.0001 & " & " & " & " & " & 3 & -0.8 & +6.8 & -0.9 \\
\hline 0.01 & " & " & " & $40 \%$ & $\left(\mathrm{CH}_{3}\right)_{2} \mathrm{CO}$ & 4 & -0.2 & -0.3 & -0.1 \\
\hline
\end{tabular}

+ Average of 3 determinations

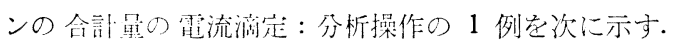
$0.1 F$ ヨウ化力リウム溶液乙 $0.1 F$ ヨウ素酸 カリウム 溶液总行 $10 \mathrm{ml}$ はかりとって滴定セルに入れ，1F 硝 酸カリウム $10 \mathrm{ml}, 0.5 \%$ ゼラチン溶液 $4 \mathrm{ml}$ およびエ タノール $35 \mathrm{ml}$ 在添加し, 再蒸留水を加えて全量を 100 $\mathrm{m} l$ に守。この被滴定液老 $5^{\circ} \mathrm{C}$ 以下に冷却したの方， 回転白金電植： S. C. E. 总用いる短絡電流滴定法によ って $0.1 F$ 硝酸銀標潗㳸で滴定与る. 滴定曲線は Fig. 5 の（2）の上らに当量占付近までの電流增加はわずかで あるが，こ秃先過ぎると過剩の銀イオンの抬散電流によ

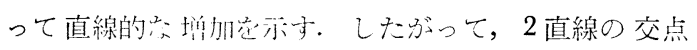

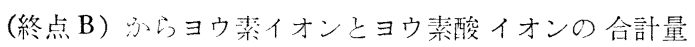

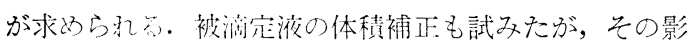
響はほとんど忍以ら秃なふった。定量結果を Table IV に示す.

Table IV の上にに，存機溶媒炎添加しなくても $5^{\circ} \mathrm{C}$

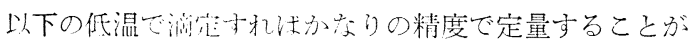
できる.し出し，20〜40\%のアルコールまたはアセト ンを添加して低温で湖茫したほうが計算值に近い結果が 得られる何向が琶わられたのて，比較的うすい溶液の場 令に性存機溶媒の存有下で涌却したのち滴定することぶ

望ましい.

$$
4 \text { 綃語 }
$$

ヨウ素イオンとヨウ装酸イオンの混合液を電流滴定法

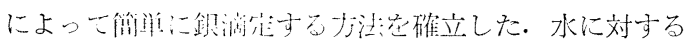

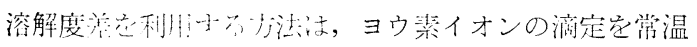

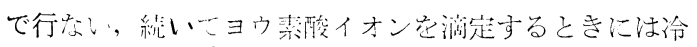

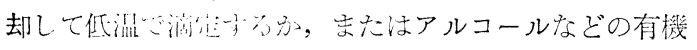

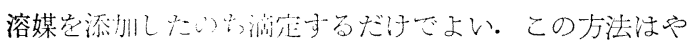

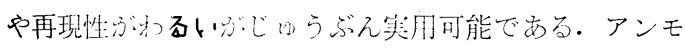

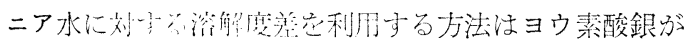

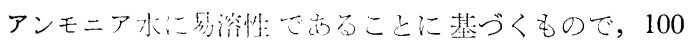
倍以上のヨウ其酸イオンと㥍存寸る微星のヨウ素イオン
をも容易に精度よく定量できるという特長至持ってい 子.

$$
\left(\begin{array}{l}
\text { 昭和 } 40 \text { 年 } 11 \text { 月, 日本分析化 } \\
\text { 学会第 } 14 \text { 年会において講演 }
\end{array}\right)
$$

\section{交献}

1) 化学大辞典編集委員会編: “化学大辞典”, 9 卷, p. 451 (1962), (共立出版).

2) F. P. Treadwell, W. T. Hall : "Analytical Chemistry", 8th Ed., Vol. 2, p. 389, 615, 617 (1935).

W. F. Hillebrand, G. E. F. Lundell : "Applied Inorganic Analysis", p. 589, 591 (1953), (John Wiley and Sons Inc., New York).

上野景平：“キレート滴定法”，p. 207 (1956), (南江堂).

館更, 永田美之助, 竹盛欣男: “分析化学講 座”, 4-B， p. 835 (1953), (共立出版).

石橋雅義: “定量分析実験法”, 普通編, p. 472 (1953)，(富山房).

3) 岩崎岩次, 内海喩, 米原範伸：日化， 85, 36 (1964).

4) 池田早苗, 西田義郎: 本誌, 13, 133 (1964). 池田早苗, 西田義郎: 同上, 13，433 (1964). 池田早苗，西田義郎，吉田武：同上，13，690 (1964).

武者宗一郎，池田早苗：同上，14，795 (1965). 池田早苗, 西田義郎: 同上, 15, 610 (1966).

5) H. A. Laitinen, W. P. Jennings, T. D. Parks : Ind. Eng. Chem., Anal. Ed., 18, 355, 358(1946).

6) I. M. Kolthoff, J. T. Stock: Analyst, 80, 860 (1955).

7) I. M. Kolthoff, J. J. Lingane : "Polarography", 2nd Ed., Vol. II, p. 898 (1965), (Interscience Publishers Inc., New York).

8) I. M. Kolthoff, W. E. Harris : Ind. Eng. Chem., Anal. Ed., 18, 161 (1946).

$$
\text { is }
$$

Amperometric argentometry of a mixture of iodide and iodate utilizing the difference in solubilities. Sôichirô Musha*, Sanae IKEdA and Girô Nishida** (*College of Engineering, University of Osaka Prefecture, Mozuume-cho, Sakai-shi, Osaka-fu; **Technical College of Tokushima University, Minamijosanjima-machi, Tokushima-shi) 
Short-circuit amperometric titrations of a mixture of iodide and iodate with silver nitrate solutions using a rotating platinum wire electrode $(1000 \mathrm{rpm})$ have been investigated at zero applied potential with an S. C. E. or a merucry-mercuric iodide electrode.

Two methods were proposed of which one (I) is based on the difference in solubilities of silver iodide and silver iodate in an aqueous solution, and the other (II) is based on the difference in their solubilities in a dilute ammoniacal solution.

(I). Suspended silver iodide does not cathodically depolarize the rotating platinum electrode due to its low solubility, while silver iodate readily gives rise to a cathodic current because of its much greater solubility in an aqueous solution at the potential of S. C. E. Iodide in a neutral supporting electrolyte such as potassium nitrate, ammonium acetate or sodium acetate can therefore be titrated with silver nitrate at room temperature $\left(c a .20^{\circ} \mathrm{C}\right)$ in the presence of iodate. Iodate can then be titrated in the presence of $0.02 \%$ gelatin after cooling the solution below $5^{\circ} \mathrm{C}$, or by adding organic solvent such as ethanol (30 40 vol.\%) at room temperature to decrease the solubiltity of silver iodate. The possible determining ranges of concentration were $0.001 \sim 0.01 F$ for iodide and 0.002 $\sim 0.01 F$ for iodate. The relative errors were about $\pm 2 \%$.

(II). Silver iodate dissolves in a dilute $(0.1 F)$ ammonia water, while silver iodide essentially does not. Iodide in the presence of iodate can therefore be titrated in a dilute ammoniacal solution by amperometry with a rotating platinum electrode and silver nitrate solution at the potential of mercuric iodide electrode, using the indicator current of silver ammonium complex. The total amount of iodide and iodate is determined by titration in a neutral supporting electrolyte below $5^{\circ} \mathrm{C}$, in the presence of $0.02 \%$ gelatin and 30 40 vol.\% ethanol at the potential of S.C.E. The determining range of concentration of iodide in the presence of iodate was $0.0001 \sim 0.01 \mathrm{~F}$. The relative errors for $0.001 \sim 0.01 F$ iodide were about $\pm 0.5 \%$. The total amount of iodide and iodate in the concentration range of $0.002 \sim 0.02 F$ was determined with the error of about $\pm 1 \%$.

(Received Sept. 29, 1967)

\title{
く形波ポーラログラフ法による鉄鋼およびアルミニウム 中の微量マンガンの定量
}

\author{
須藤 恵美子， 大河内 春乃*
}

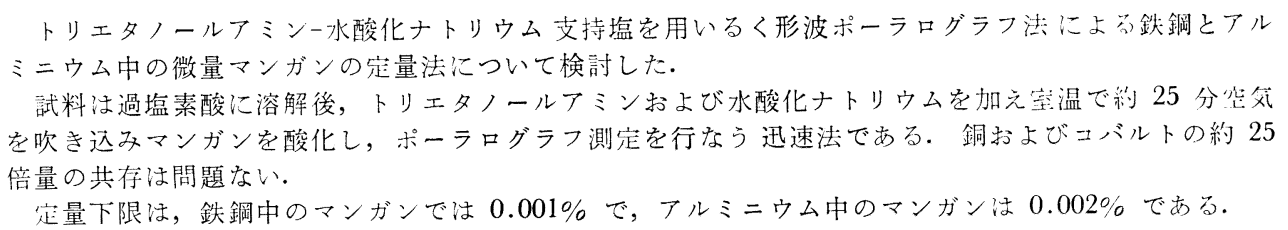

\section{1 緒㝘}

マンガンのボーラログラフィーによる定量注直流ポー ラログラフ法による報告1) 8)が数多く見られるが，その うち金属中のマンガンの定量法としては鉄鋼, コバル ト，ニッケルフ中の報告があるのタで，いずれも感度が わるい，藤永ら 92 にくく形波ボーラログラフ法を用い る硫酸第二鉄アンモニウム中の微量マンガンの定量の献 告があるのみである。

*科学技術庁金属材料技術研究所：東京都目黑区中目 黑 $2 丁^{\circ}$ 目
そこで著者らはく形波ボーラログラフ法によりアルカ

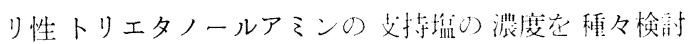
し，鉄鋼中の $0.001 \%$ マンガン至鉄の其存のもとで簢単 に定量すること安得た。こ狄在交流ホーラログラフ法た

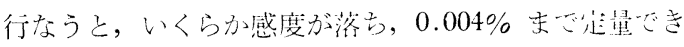
万.

また本支持塩のトリエタノールアミンはアルミニウム

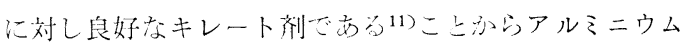
中のマンガンの告量䓘研究し，アルミニウムートリエタ

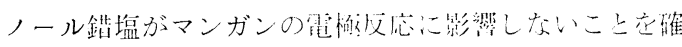

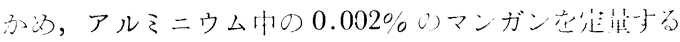

